\title{
O gado e as larguezas dos Gerais
}

\author{
CARMO BERNARDES
}

$\mathrm{N}$

OS GERAIS, cujas raias podem ser imaginadas como englobando todo o Sul do Maranhão, Norte de Goiás e Oeste da Bahia e de Minas Gerais, espaço geográfico dado como sendo os sertōes, o gado era criado à lei da Natureza, solto no mundo. Os horizontes, os limites; e o olho do vaqueiro, o vedo.

O leigo em criatório extensivo estranha que tenha havido esse sistema de criatório. Onde há arraigada a mentalidade do arame farpado, ninguém aceita a idéia de se criar na largueza. Acreditam que as criaçốes largadas à-toa, sem nenhum vedo como sujeição, desguaritam; e que é preciso trazê-las no rodeio, e que um pastoreio nessas condiçôes, sem os apartadores e as invernadas limitadoras do espaço, exigiria o concurso de muitos vaqueiros para cuidar de pouco gado. Ouvimos o criador sulino dizer num desalento: "Crio aqui umas criaçóezinhas no tapume de cinco fios de arame, e óia lá: tề-tê, lê-lê, estou às voltas com uma criação sumida!"

O prelecionador tem de arregimentar paciência, gastar tempo para induzir o interlocutor cru em história, convencê-lo de que o boi rústico do sertão possui um acentuado sentimento telúrico, ama os seus pagos e defende os seus rincôes. Arredar das proximidades do terreiro às vezes arreda, mas nunca sai andando sem destino, até desaparecer dos olhos do dono. Isto a experiência confirma, é uma sabedoria que a tradição perpetua. As querências dos rebanhos inspiraram a musa sertaneja e já serviram de tema a largas tiradas literárias dos sertanejos do asfalto.

Há a crença generalizada no sertão de que o boi curreleiro só fica sossegado na pastagem, que não é sua, enquanto não troveja. Vindo o mormaço, o trovão ronca nostálgico, anunciando as primeiras chuvas, e o boi forasteiro desespera. Despreza as suas amizades recentes, arrebenta o arame e arriba. E quando uma rês sertaneja morre na estrada boiadeira a carniça fica com a frente voltada na direção dos seus pagos. As vacas nunca abandonam as paragens onde thes nasceu a prole, a não ser forçadas por circunstâncias muito adversas, como o ataque das onças, $o$ endurecimento do capim ou a dificuldade de aguada nas quadras de estiagem prolongada. 
Os rebanhos sertanejos dividem-se em comunidades mais ou menos autônomas e cada unidade dessas federações ocupa uma área de pastagens, a que os vaqueiros chamam logradouro, um território que reuna o mínimo de condiçōes de sobrevivência, como sejam pastagens abundantes, aguada com acesso franco, sombra fresca de arvoredos para o refrigério dos meio-dias queimosos.

Ao escolher um ponto para botar um criatório no sertão, o sertanejo examina se na regiăo ele pode contar com o mínimo de três faculdades: largueza, boas aguadas e pasto com abundância; $\mathrm{e}$, melhor ainda, que não haja, na redondeza, furnas e grunas habitadas por morcegos hematófagos, que atacam e matam as crias recém-nascidas.

Se o gado bovino fosse como o súno e o equiino - indisciplinados, bandoleiros -; sem nenhum apego ao chão em que nasceram e se criaram, a conquista dos espaços vazios ainda estaria longe de ser feita. Há uma suposição histórica de que as extensóes territoriais deste imenso país foram conquistadas pelo gado andando na frente e os vaqueiros atrás, apossando-se dos campos freqüentados por suas criações.

A fortuna de um criador é avaliada pelo número de reses que possui, e o quanto possui é calculado pelo tanto de logradouros da fazenda. Logradouro é o território onde é empastada uma determinada ponta de gado, que o vaqueiro visita regularmente, mantendo contato com as reses ali alongadas. Havia proprietários que nunca tiveram o prazer de ver reunido todo o seu rebanho. Os vaqueiros comentam: "Fulano possui gado que ele nunca viu reunido! Todo ano gado dele abre dois, três logradouros!...”

E como se faz a lida nessas condiçóes? No sul, onde em vez dos logradouros há a invernada, maneja-se o gado no custeio. No sertão, no mundo aberto, quem zela é o olho do campeiro. Pela manhã, bem cedo, saem correndo os logradouros a ver as vacas que estão amojando, uma criação que estava com bicheira na orelha; campear uma ternadinha que não é vista no último campo. Os logradouros têm de ser visitados antes do sol subir e o tempo esquentar muito, que é quando as criações estão nos descampados, pastando o capim serenado. Durante a volta do dia, quando o capim enxuga e resseca com o sol quente, as manadas embrenhamse no mato, à procura de um piquizeiro, desarreia e peia o animal de sela, arma a rede e passa por uma melhora, espera vir a fresca da tarde.

Se a vaca que estava chegadinha deu cria e foi encontrada, ela é tocada para a fazenda, ou para o retiro mais próximo. Se a cria ainda está molezinha, é levada na cabeça da sela, a mãe berrando atrás.

As bicheiras do gado eram curadas lá mesmo no campo, onde a criação 
bicheirenta fosse encontrada. Na garupa da sela o vaqueiro conduz os alforjes com as tisanas de curar, os ungüentos aplicáveis no tratamento das feridas - melado de casca de barbatimão, óleo de copaíba, azeite de mamona - e os instrumentos de alveitar. Corre-se o laço no bicho doente, chega-lhe a peia, dá com ele no chão e, escangotado, aplica-lhe o curativo bruto. Se é bicheira, o tratamento é mel de fumo, e a teriaga é conduzida num cornimboque. Se quebrou o chifre ou se feriu num potaço correndo no mato, usa-se o melado de sambaibinha. Se a rês está entrezilhada, com sintomas de aguação (anemia perniciosa), seria o caso de se aplicar uma sangria. Puxa-se a musculatura do pescoço para fazer desencontrarem-se o couro e as carnes na altura da jugular e pica-se com o fleme. O primeiro jorro da hemorragia é aparado numa folha e posto de lado para coagular. Pela proporção da linfa que aparecer separada do coágulo, o laboratorista bronco avalia o grau de anemia do animal enfermo.

Esgotada a porção de sangue julgada necessária, segundo o critério empírico, o veterinário solta o feixe de músculos arrepanhados e a hemorragia é sustada pelo desencontro dos tecidos. Recolhe os instrumentos de alveitar, puxa a língua da rês para o lado e deita-lhe a boca abaixo uma boa porção de sal torrado, tira-lhe as cordas e dá por concluída a sua missão de vaqueiro zeloso.

Mas as coisas não se passam assim, tão românticas e simplistas. Ocorreria que a rês procurada seguiu caminhos contrários aos do seu rebanho, desgarrou-se e abandonou a madrinha, amoitou-se nalguma biboca impossível. Principalmente se doente grave, não agüentando mais o arrastão da manada.

Cabe aqui uma consideração. Comentam hoje, entre suspiros nostálgicos, que antigamente não dava surto de peste no gado. É que a saúde dos rebanhos era devida à presença dos predadores, nada menos do que três espécies de onças que assolavam os campos gerais. A rês que, adoentada, não conseguia acompanhar a sua manada, unida e vigiada pelo touro avalentoado, era infalivelmente agarrada pelo felino famélico. Dessa forma era feita, com muita segurança, a profilaxia natural, que nenhuma técnica e medicamentos modernos podem igualar.

Seria o caso de se indagar por que as onças não atacavam as vacas que, para dar cria, teriam de ficar de arribada, desgarradas da sua maloca. Nesse caso particularíssimo, em mais um aspecto, a Natureza se mostra surpreendentemente sábia. Dado o maior teor de gás carbônico na mistura do ar ambiente, durante a noite, os animais de sangue quente, os homotermos, nessas horas, experimentam um estado de letargia que se manifesta pelo sono ou por um relaxamento nervoso favorável à esvurmação da cria, e o gado pousa sempre reunido nos malhadouros e a vaca prenha no meio dá a cria protegida. $O$ boi dos gerais é um animal rústico, legítimo produto do meio, vigia a malhada; o bezerro nascituro da noite já pode sair andando, acompanhando a mãe, desde as primeiras horas do dia. 
Era por esse infalível recurso que a profilaxia dos rebanhos se fazia, e os surtos de epizootias não ocorriam.

Pelo instinto maternal, ela sabe que o filhote necessita dormir sono mais demorado durante o dia. Mas é necessário encontrá-lo, desamoitá-lo, para curar o umbigo, que quase sempre panha bicho, e o vaqueiro queixa-se daquelas vacas muito velhacas que se encasquetam, recalcitrantes, em não mostrar a cria que deixam socada numa moita, quase sempre embuçada na macega.

Lá está ela, pastando tranquiilamente no descampado, a pouca distância de sua maloca, dissimulando a sua condição de nutriz, paridinha de novo. Só que não pode fazê-lo plenamente. Delatam-na os peitos tumescidos e mimosos, os vazios fundos, o abatimento se mostrando na expressão dos olhos - sinais indisfarçáveis de que está amamentando. $O$ bezerrinho sumido e ela, fazendo-se de esquerda, se nega a mostrá-lo. Está escondido, o vaqueiro bem o sabe, o bichinho se embioca, num sítio arredado, bem amoitado na macega, que só a mãe sabe onde fica. Esses embaraços que o peão experiente tem como vencer. Coloca-se num ponto de observação bem oculto, deixa lá longe o animal de sela, e fica de espreita a notar a direção para a qual ela está a vigiar, a aplicar os seus cuidados. Tapa o nariz, imita os balidos do bezerro novo e observa se ela reage com sintomas de sentimentos maternais. $\mathrm{O}$ peão vasculha os arredores com sua visão devassadora, às vezes inutilmente. A cria continua somítica, só vem se encontrar com a mãe quando esta tem a segurança de que não está sendo seguida. Se esses recursos se resultarem frustros, resta ao campeador voltar ao campo destinado a pernoitar na espionagem, se necessário. $\mathrm{O}$ animal de sela é desarreado e peado, posto a pastar num encosto, o peão se oculta protegido por uma dobra do terreno, se possível contra o vento, e só se retira após surpreender o bichinho no seu esconderijo misterioso. E quando ele já está esperto e durinho costuma espantar-se, alevantar-se e fugir como um animal selvagem, e dá tora primeiro que o peão possá levá-lo às cordas.

Os bezerros nascido nos gerais são arrebanhados, recolhidos num chiqueiro da fazenda ou do retiro que superintende o respectivo logradouro, onde a vaca mãe reside. Cada um é amarrado pelo pescoço com o relho ou com o sedenho. Os machos, que vão engrossar as boiadas a serem recriados nas invernadas de outras terras e findarão nos matadouros, ficam presos menos tempo. As fêmeas, que vão ficar no gado de criar, demoram por mais tempo no custeio a fim de se familiarizarem com as cordas. Finda essa temporada, quando a bezerrada já está esperta, então é assinada com o moirão da fazenda na orelha esquerda e com os piques, espécie de calendário, na orelha direita, indicadores da era do nascimento.

Săo de importância nos hábitos do gado sertanejo que cada vaca, quando está com sua cria estagiando no chiqueiro, passa o dia no seu rincão; de forma alguma a rês se conforma em pastar nas paragens que não são a sua. Se acaso seu 
logradouro fica doutra banda do rio, a vaca parida se sujeita ao sacrifício de atravessar a nado pela manhã, vir dar de mamar, voltar para o seu pasto, à tarde fazer o mesmo, amanhecendo sempre na porteira do curral a gemer ternuras ao filho preso. Se por algum imperativo muito forte for forçada a optar, ela não hesitará em preferir o logradouro ao filhote. Muitas vezes a fazenda interrompe o estágio de partidas inteiras de crias novas, porque as mães, apegadas às sua querências de pastagens distantes, se negam a vir dar de mamar. Os bezerros são levados aos sítios do seu nascimento, e será o caso de se fundar aí um novo retiro.

Do maior ou menor cuidado da fazenda - o tempo de reclusão dos bezerros - depende a docilidade dos rebanhos. Não havendo amiudadas visitas às malhadas no campo, o gado poderá ficar arisco, correndo com a aproximação dos peóes, embrabecer e até virar gado de brabeza que é ó alçado no sul e o baguá no Pantanal.

Essas categorias são escalas de valores dos rebanhos de cada fazenda. A rês que virou brabeza passa ao domínio público; condição pior do que a do animal selvagem, vez que este tem a proteção do Estado, embora simbólica. Não leva a marca do dono, virou bicho e perde o valor de mercado. De sorte que no sertáo definem-se $o$ gado manso, $o$ arisco corredor, e o de brabeza. Manso é aquele que, embora seja gongueiro, gosta de andar sumido nas brenhas, vacas que escondem o bezerro novo, que fogem do curral por amor dos seus logradouros abandonando a cria - com tudo isso obedecem o aboio, andam tocados sem maiores aborrecimentos. $\mathrm{O}$ arisco é o corredor que foge à aproximação do vaqueiro e dá trabalho para ser levado ao curral. Brabo é o que não vai tocado, só se entrega atrelado ao pescoço do boi sinueiro, domado espencialmente para esse mister. $E$ o boi de brabeza é aquele que nasceu e se criou sem nunca ter visto um homem, nem de longe. É o animal que virou bicho, caiu definitivamente na selvageria; e, nesses casos, é a fera mais perigosa dos gerais. Não traz, naturalmente, a marca da fazen$\mathrm{da}$, sinal algum que o identifique como propriedade de quem quer que seja. É bicho como qualquer animal selvagem e quem o abate é dono.

Uma ovelha má bota todo um rebanho a perder, diz o provérbio, quando uma vaca vai ficando arisca, o vaqueiro zeloso apressa em dar um jeito nela e toma medidas acauteladoras, pois há o risco das suas companheiras se desencaminharem e seguirem-lhe no mesmo caminho. E aí estará iniciado o embrabecimento do rebanho inteiro. Se é assim, o recurso será amarrar-lhe no pescoço um cambão que lhe tolha os movimentos; e, às vezes, usam-se dispositivos mais cruéis, como a tora de madeira amarrada no jarrete. Naturalmente, essas inventivas bárbaras não se aplicam para corrigir desvios de comportamento de rebanhos inteiros. Se a vaca treteira não é tão boa criadeira, aparta-a para o cercado da engorda de onde sai para o toco do açougue e vira matutage. Com punições assim, tão radicais, nos sertóes de Goiás e Bahia há muito pouca possibilidade de uma ovelha má botar todo um rebanho a perder. 
Parece que certos animais - pelo menos o gado bovino aparenta isso possuem a faculdade de perceber tudo quanto o bicho homem pode fazer contra ele. O boi selvagem, o de brabeza, é de fato agudíssimo, tino descomedido, e para fugir ao perigo é iluminado por uma centelha de raciocínio.

É um bicho danado!

Outras espécies são, de comum, ingênuas e primárias; o mais que alguns sabem fazer, para servirem-se dos recursos do meio em seu favor, nas horas apertadas, é trepar nos paus ou se enlocar. Já o boi fera é outra coisa: sabe se esconder; não cai em armadilhas; evita frequientar lugares em que vê rastros de cavalo; está sempre de venta aberta sentindo o correr dos ventos; não pasta nos descampados; não se mistura com gado manso. Nisto há uma exceção: pode ser que um macho seja atraído por uma fêmea no cio, e quando é assim o desventurado amoroso costuma casar a avó mal-casada, levar um tiro de carabina no coração.

Também a ferocidade de um bicho desses surpreende e parece delatar-lhe incipiente conhecimento de causa. $O$ vaqueiro avista-o à distância e reconhece logo que é uma brabeza. O animal se mostra ressabiado, hora e outra baixa a cabeça, tira uma rasourada de pasto verde e volta a se levantar nas pontas dos cascos a perscrutar os arredores, a sondar distâncias - é um boi de brabeza, com certeza.

Se o vaqueiro não pode contar com o concurso seguro do animal de sela em que vai montado, larga a fera pra lá, desiste de dar nela, a parada é indigesta, deixa para melhor oportunidade. Uma rês arisca pode ser pega, levada na chincha com dois laços. Já o boi de brabeza - nunca. Se na corrida bruta, de esmoer cerrado, o cavalo chega e o peão manda o laço, no que o trem sente a cócega da corda a arrochar-lhe o pé dos guampos, joga os traseiros pra lá, dá ponto de briga e vem à ilhapa. Nesses lances de audácia e temeridade o êxito está no cavalo ser adestrado para isso, o peão frio, senhor dos seus reflexos. Arredar da frente na hora certa, no tempo exato, mais que depressa enlear o laço num embaraço, num tronco de árvore ou em alguma moita cerrada, à conta de dar tempo de manobrar a carabina e atirar. E visar sempre a ponta do quadril que, quebrado, tolhe-lhe os movimentos; a fera urra mas está entregue.

O boi de brabeza não se deixa dominar. É dos tais que morre mas não se entrega. Todo campeador sertanejo sabe disso. $\mathrm{E}$ não há esse peão que tenha brigado com brabeza que no seu repertório de causos não constem lances dramáticos de caçadas que resultaram em sangueira e tripas enleadas nos gravatazais, vísceras do cavalo que o boi furou com as aspas agudas, desgraceiras a que só as árvores retorcidas e a japecanga dos cerradōes dos pés da serra serviram de testemunha. 
Difícil, mas um boi desses pode ser pego de traição. O campeador solitário, que esquadrinha bibocas nos ermos, se vislumbra motivos de que por ali está batendo um brabeza, arreda sorrateiramente, evita deixar motivos delatadores de sua presença, para não escaramentar o bicho. Pois, se ele vier a perceber que o seu refúgio foi violado cai fora, embrenha-se nos socavôes mais remotos, e por lá costuma ficar por longo tempo, pastando ervas e folhas de árvores, bebendo orvatho ou chupando minadouros nos pés da serra.

Se vimos falando apenas de um boi de brabeza, nada dizemos de vaca, temos como nos justificar. A vaca, sem a proteção do touro avalentoado, desgarrando-se das manadas a onça pega. $\mathrm{E}$ o touro, vigoroso e bem-armado, onça nenhuma se aventura a atacar.

Para apanhá-lo à traição, a providência pode ser botar fogo num furado de capim situado mais próximo do sítio onde ele está batendo, para que a brota emergente formando um prado oloroso e suculento e cinza rica em potássio e sódio, sirva-lhe de atrativo forte. Se o terreno está virgem, não apresenta nenhum indício de presença passageira do bicho homem, não se vê rastro de cavalo, ramo quebrado, sinal algum suspeito na soledade do ambiente ermado, às altas madrugadas ele vem pastar; e, vezado nisso, demora às vezes rasourando a relva tenra até $o$ sol subir, e acaba levando uma bala na ponta do quadril que the mandou $o$ peão malvado que estava de tocaia por detrás de pedras, contra o vento.

Alguns proprietários residiam fora, pelas cidades grandes, e seus vastos latifúndios olhados pelo vaqueiro, homem de confiança, uma espécie de sócio interessado. De ano a ano, na data certa, prestava conta, trazia o patrão informado, e ser arisco e brabo era o comum do gado. O pegueiro tinha ordens de formar retiros, quantos o rendimento das manadas o exigisse, entrepostos de criatórios dentro dos domínios do patrão, onde as malocas fossem empastadas. Botava um preposto lá, de forma que uma fazenda era sempre uma comunidade composta de muitos moradores. Não havia custeio propriamente dito; os rebanhos à lei da natureza, eram apenas olhados lá pelos campos mesmo, e salitrados nos barreiros de argila salobra e nas cinzas das queimadas. No tempo certo, todo ano, eram feitas as vaquejadas, devoção a que não se podia faltar. No curral o boi vinha à força, pego no campo a casco de cavalo.

Quando caem as primeiras lufadas de chuva, com os gerais lambidos pelas queimadas e que vão apontando nas touceiras os primeiros renovos do agreste, $o$ gado que esparramou escabreado com a seca, saiu caçando aguada e o que comer, pega a voltar e se reunir nos seus logradouros. A torna das águas desperta energias adormecidas na Natureza inteira. Nos meses últimos do estio há um desalento medonho em toda coisa, tudo fica como que entorpecido, quieto e triste. Águas que no inverno brotavam por toda banda nessa quadra some chão a dentro, vão 
para as camadas mais profundas dos estratos. As árvores decíduas derrubam as folhas devido à adurência doas ares. As aguadas esturricam e os rios mostram as entranhas martirizadas. A desolação e a bruma seca abreviando os horizontes provocam na gente sufoco e arrochuras. Os pássaros não cantam, cessa toda a sinfonia na Natureza, uma flor sequer aparece entre os gravetos castigados dos cerradóes e não se ouve um mugido para romper a quietude opressora dos gerais.

No findar de agosto, depois da ventania e dos chuvisqueiros, da flor da caraíba, o tempo enfarrusca e a fumaça do mormaço tolda os cocorutos das serras. $\mathrm{O}$ vento geral desenfreado topa nos talhados das montanhas, revolta em redemoinhos brabos, de arrancar árvores com a raiz e fazer correr pra cima a corrente escassa dos rios e ribeirões que já vão tomando água.

Troveja, os elementos vão tomando forças, com vagar, mas sem detença, e a voragem vai sacudindo a Natureza. O círculo constringente dos horizontes abafados pesa como chumbo, o sol empalidece, os ermos enchem-se com o rechinar da cigarrinha zumbi, a melancolia domina tudo. Chega a hora em que os relâmpagos sarjam os novelos das nuvens que se vão formando pouco a pouco, $\mathrm{e}$ parece que o aguaceiro vem rolando ao rés do chão. E, num crescendo, amiudam os coriscos, ribombam trovoadas, a borrasca avança avassaladora em ondas descomunais, varre as baixadas e tomba nas encostas. $O$ chão esturricado em vez de embeber-se desde logo, no início faz é repelir as primeiras pancadas do temporal. Pelo efeito da calefação, é formada uma evaporação densa e tumultuosa com o céu despejando na terra e a terra chovendo no céu.

Cessada a tribusaina, o tempo subverte-se, o anverso do quadro vai se destampando, a Natureza volta às boas com o esboço de um riso cálido, apaziguado. Aí desanda em tudo um desespero maluco de sensualidade em todos os viventes, a vida clama por fecundação, é um nunca se acabar de danura. Do chão tresanda o cheiro provocante de terra molhada; os pássaros alvoroçam agitando os ramos, convocam os parceiros a poder de cantigas sedutoras, pios dolentes, pipilos blandiciosos, dobrares canoros aconchegantes - é uma pletora de notas discordantes, como se os figurantes de uma orquestra de cordas houvessem baralhado as partituras.

Os bichos desabafam-se em pinotes, o gado reúne-se em malhada, cada talhão trata de regressar aos seus logradouros puxado por uma vaca erada, mãe de muitas crias, vez que os gerais vão se arrebentando em flores e deitando brotas. Com as primeiras chuvas chega a quadra dos idílios, dos esponsais, de estupendas proliferações.

Volta o sol, mas com ares demudados, sem a austeridade dos dias anteriores, sem o embuçamento brumoso, e sim inspirando a alegria universal, abrindo para todos os viventes um riso meigo de ternura. 
Das primeiras chuvas ao arrebentar a inflorescência, decorre cerca de uma semana. Brotam touceiras, germinam sementes até então invisíveis, sob as cinzas das queimadas, a vegetação despida se veste, e o campo recama-se de malmequeres, de paratudos e de um sem número de florzinhas graciosas que o classificador sertanejo ainda não batizou; a escova-de-macaco faz dos cobertões do cerrado de dois pelos aquarelas pinceladas a esmo - e é em tudo uma permanente emulação de revivescência.

As campinas e chapadóes carbonizados transmudam-se em ondulações verdejantes, as grotas em regatos e estes viram riachos caudalosos, as aguadas maiores tomam status de rio. Então começa o reajuste: desamoitam os bandos de araras que de manhã $\mathrm{e}$ às tardes estendem colchas de retalhos no espaço, indo aos coqueirais e voltando ao pouso; as seriemas alegram os rincóes elevando suas queixas sobre os demais rumores da criação; os rebanhos se reúnem guiados pelas madrinhas, cada lote fixa-se de novo em seu logradouro - chegou o tempo das vaquejadas.

Só os grandes criatórios fazem as vaquejadas. Vêm os boiadeiros, que já tinham combinado com o dono da fazenda morador fora, lá pelas cidades grandes, e os peões tiram uma temporada em que só fazem pegar boi arisco. Comparece a vaqueirama da redondeza, vêm montados nos seus animais de campo, arreatas. e laços seus; não podem faltar com o adjutório ao vizinho. Todo ano é isso: ganham dia, cooperam uns com os outros, modo de convivência da gente sertaneja. Isso assim é o costume de não deixar o outro labutar só, abrange uma extensão de muitas léguas em derredor. De uma fazenda passa para outra, tudo de combinações feitas antes, a quadra propícia bem dividida a que nenhum fique prejudićado.

Diga-se, portanto, que o ajuntamento de peões para as vaquejadas é feito por força das mesmas causas que levam a se agrupar a companheirada para a limpa das roças, serviço que se um só for fazer não sai a tempo. Tem mesmo é que ajuntar muitos, limpam uma roça num dia, noutro dia passam para outra, e nessa lida salvam as lavouras de uma região inteira, plantação nenhuma morre no mato, assim como nos criatórios nenhum boi escapa de ser enlotado na boiada.

O mal é que os boiadeiros são uns apressados, o prazo para formar boiadas é sempre curto; também o criador necessita entregar logo suas partidas; e, sendo assim, há de se reunir maior número possível de peões e vaqueiros, uns para pegar, outros para sujeitar a boiada no rodeio, porque pasto vedado não existia.

Não vão ao campo reunidos; não dão em cima de uma rês como se fosse uma carga de cavalaria na pega do novilho que desgarra e corre. Vaquejada é feita de potreadas a dois e três cavaleiros, cada um desses grupinhos vai acampar num 
rincão, e de tarde se reúne na fazenda ou no retiro, conforme seja o caso. O lugar das festas vai mudando, os talhões de boiadas vigiados nos rodeios, os peões revezando, descansando uns aos outros no varar das noites acordados; só no final de toda a pega do gado é que se dá o ajuntamento para a marcação e a entrega ao boiadeiro, que assina o recibo e o comissário toca.

Todo apreparo é feito com antecipação de muitos dias. O que mexe com artesanato de couro arruma as cordas, ajeita as sogas, vê os relhos, a tralha completa, e tem que retocar os cercados da tropa ficar e onde tem uns tantos bois sinueiros bons de trela. $O$ reforço de carne seca é feito, $o$ arroz limpado no pilăo foi cuidado em tempo, a rapadura e a farinha há de ser com fartura.

No correr de uns dois dias a peonada estará toda reunida na fazenda. À noite cavaqueiam-se até certa hora, trazem os casos acontecidos mais de fresco, estão em voga as surtidas de um peão sacudido que pega rês braba com a mão. Vem a ceia, e ali conversam mais um pouco, mas terão de dormir mais cedo, porque a lida que vão pegar promete ser de arrancar rabo.

Num criatório muito grande em que, de regra, o gado era mal zelado, um peão, por mais sacudido que seja, nunca pega mais de três. Façanha desse porte depende da coragem do caboclo e da destreza do cavalo.

O campeiro, que parece ir distraído, de uma hora para outra avista o garrotinho, ou um magote deles. Lá estão de cabeça baixa. Tira-se a base se eles estão de bom tamanho, na média que o boiadeiro exige. Aí o peão pára, dá sinal ao companheiro. Combinam, acertam de que lado vão chegar para jogar o cavalo em cima e correr o laço. É tomar chegada e prelibar o prazer da escaramuça selvagem. Se o cavalo dá para chegar, de molde a poder agarrar na seda do tucura e dar o golpe, tombar, montar em cima e passar a soga na cabeça - muito bem; se não, o recurso é correr o laço, é amarrar num pau. Na corrida desabalada é ter cuidado com os arraiais de tatu-bola e do piorra, que furam seus buracos a prumo, debaixo do capim. É um perigo o animal enfiar o pé num buraco desses. Aí roda, o cavaleiro pode não dar conta de saltar fora a tempo, cai junto com o animal, estronda o crânio, arrebenta-se todo por dentro. Esses flagelos, nos campos, causam temor. Um arraial de tatu, um redope de pedra canga, com a macega batumada encobrindo, são acidentes prontos a tirar a vida do cavaleiro.

Concluída a pega dos bois de uma fazenda, o comissário levava aqueles, parava durante outra temporada em outro piāo. De criatório em criatório, as vaquejadas prosseguiam até meados de novembro, com as chuvas pegadas, o tempo certo de tocar boiadas.

Dessa atividade primitiva vêm os traços culturais da nossa formação, como 
ascendentes de uma sociedade pastorial. A agitação da opinião pública voltada para os espaços ainda de população rarefeita de toda a extensão que vai de Brasília, pelo interior do Maranhão, até as raias do Pará, exige remontar origens. Nessa área ainda são encontrados quase intactos restos das relações de produção que vigeram no século XVII.

\section{A boiada}

Um, que acima dele, numa boiada, só o comissário e o capataz, é o contador. Este há de ser seguro na parte que lhe toca, e tem que fazer por merecer a confiança da peonada, mormente do arribista. Ele não pode errar a conta, com pena de dar maçadas. Se a sua contagem acusa boi a mais, é de achar que entrou criação na boiada, e aí vai ser preciso separar, apartar, largar pra trás o adventício. Nesse caso tem que passar a trenheira toda de novo afunilada na porteira, ou seja, numa cava, com o contador, o capataz e o comissário - se este estive presente -, colocados do lado da marca; ou seja, do lado direito, eles reparando com afinco a ver se notam a presença de criação estranha.

O único meio seguro de separar um boi estranho numa boiada é pela marca. Quase sempre - difícil ser o contrário - o boi de boiada está ferrado de fresco, com o queimado da marca ainda escuro, levantando escaras. E o estranho, nem sempre. É fácil, portanto, fazer a separação.

O mal maior é se a contagem acusa boi a menos, e foi erro do contador. $\mathrm{O}$ arribista, nesse caso, vai voltar para campear, pegar um boi que não existe. Para evitar essas maçadas, o gado deve ser contado todo dia. Nesses casos a distância prá trás, ao longo do trecho a ser campeado, é curta, os rastros ainda estão frescos, o peão na arribada nota logo se houve equívoco. Ele volta reparando, examinando fora da rastaria da boiada, e se não viu em lugar nenhum vestígio de cascos espalmados e gastos, e que o rastro é de criação viajada - suspeita logo que houve erro de contagem. Depois de averiguar, de ter certeza de que o contador trastejou, o peão se põe de volta à boiada, e dá discussão.

\section{Mas são casos raros.}

Dos contadores de bois cada qual tem lá o seu sistema de contar em que ele confia. Uns contam abarcando com os olhos os grupinhos de cinco em cinco e somando-os, de cabeça. Outros já fazem é somarem toda quantia, mas nunca a mais de cinco, vez que acima disso é sujeito baralharem as quantidades e atrapalhar a contagem. Os peóes têm que fazer a boiada direitinho, bem despontada, bem afunilada e nunca deixar passar em atropelos de bois embolados. 
Todos, entretanto, adotam a regra de separar pauzinhos: um pauzinho, como balisa, para cada cento de bois que passam. É a mesma coisa que ajuntar milho na roça: para cada balaiada que o companheiro despeja no monte, na ajunta de milho, ele separa um espiga pracolá, que fica serido o referencial. No final é só contar quantas espigas separou que fica sabendo quantos balaios tem o monte. Assim o peão contador faz na contagem das boiadas. Se a conta de gado vai para mil bois, ele separa dez pauzinhos (podem ser palitos de fósforo), e vai passandoos de uma mão pra outra, no ato da boiada passar a ele contando, cada um pauzinho valendo um cento.

Quando há condições de largueza, pode-se adotar a regra de cortar a boiada em pequenos talhóes. Contar, espiando por cima, e apontar as parcelas numa caderneta e depois somar. Mas essa não é a regra comum de contar bois.

O capataz é que toma conta de tudo. É o encarregado a quem toca comandar a peonada, ver uma coisa e outra, desde a comitiva até as condiçóes da tropa. É com quem os peões se entendem, prestam obediência e se apadrinham quando necessitam de alguma coisa ou têm queixas a fazer. Isso assim, do começo ao fim da viagem.

Às vezes o capataz é preposto do patrão boiadeiro, homem da sua confiança, a quem passa missões de responsabilidades, como a de conduzir dinheiro, de comprar boi, de fazer pagamentos. Acontece de o comissário, o que é o dono da comitiva, dono dos animais de custeio e o que conta com a peonada certa, de sua confiança, fazer, ele mesmo, as vezes do capataz.

Sobre esses homens - capatazes e comissários - sempre pesou uma acusação muito aleivosa e muito grave. Maldizem que alguns têm a má moda, em comum acordo com os outros, quando eles mesmos são os contadores, de enlotarem gado alheio nas boiadas que tocam. É uma forma de roubo a que os antigos chamavam de abigeato. Conhecemos deles, uns que adquiriram recursos, compraram fazendas e amontoaram fortunas, acusados de terem feito a vida, usando dessas mestrancias, de práticas escusas, segundo a voz geral no meio da categoria dessa gente que possui fazendas e mexem com gado.

Resta-nos definir que o peão de boiadeiro, nas suas diversas categorias, se julga um indivíduo independente nas suas ações. Ele possui, de seu, o animal de andar montado, $o$ arreamento completo, capa de chuva, o laço, a rede e os abafos de dormir. Tanto ele se ajusta entrando o animal de sela fornecido pelo patrão, indo o seu adestro, na comitiva, quanto combina adredemente de ir inteiramente por sua conta própria, com tudo de seu. Usa um chapéu de aba larga que ele arrebita de lado, por gauchada, calça botas de cano alto e não dispensa o rebenque de dar taladas na bota, quando não uma açoiteira, que é um chicotão com três 
seções emendadas em argolas, com um segmento terminado numa talisca de couro cru de dar estalos no ar. Veste calças de bombacha, não de balão tão grande como as dos gaúchos, e gosta demais da conta de rapariga.

\section{A categoria dos peóes}

A proposta foi de dar a descrição das tropas, contar como se organizavam as arreatas dos cargueiros, e de que jeito era a lida com os burros na estrada. Tivemos de mostrar a diferença existente entre a tropa propriamente dita e a comitiva, e aí entrou o assunto referente às boiadas. Nesse caso, ficamos no dever de responder a uma porção de perguntas a respeito deste último ponto, antes de nos ocuparmos exclusivamente com as tropas.

Para começar, cabe-nos informar que entre o pessoal que lida com os bois de boiada há toda uma hierarquia, não só de mando em como de competência. Carece saber que boiadeiro é aquele que possui o capital, o capitalista que compra e vende boiadas. Entre estes há também uma divisão de categoria, que vai do faiscador, que é o boiadeirinho miúdo que compra a bezerradinha dos criadores de pequena escala, e desta passa para o invernista que recria e engorda para dar as boiadas prontas ao boiadeiro magnata que compra grandes partidas, ou este mesmo invernista vende diretamente ao frigorífico. Neste caso, o preço é ajustado por arroba de carne, no pé da balança.

Fica, portanto, esclarecido que os boiadeiros das diversas categorias são os que compram e vendem boiadas. $E$ da labuta com os bois jogados na estrada eles nunca participam, a não ser para assistir às fases do trabalho, ficarem subidos na cerca olhando e dando palpites na apartação, na marcação, e querem ver a saída do gadó e a chegada ao destino, às invernadas de sua propriedade ou de aluguel, onde recriam e engordam.

Entre a peonada também há divisão de categoria. No alto está o comissário; em seguida o capataz; depois o contador e o arribista; não contando o cozinheiro mais o copeiro, têm ainda o ponteiro e o culatreiro. Daí prá baixo é a peonada comum. Tem até uma cantiga que diz assim

Sou peão de boiadeiro
que toco boi e sou ponteiro,
sou arribista e culatreiro,
em todo ponto eu sou faceiro.

Comissário é o dono da tropa de lidar com gado. É um homem bem relacionado com os peões em amizade e camaradagem e está sempre com eles 
ajustados ou apalavrados para tocarem boiadas que ele pega de empreitada dos boiadeiros para buscar ou levar a alguma parte. É a quem os peões obedecem e prestam conta e com quem se socorrem nas suas necessidades miúdas. O comissário há de ter sempre boiada para conduzir. É o tal caso de que barco parado não rende frete; os peões precisam trabalhar para viver. $E$ tem ainda uma gravidade: a tropa de mexer com gado, que é toda de burros e mulas, não pode ficar sem serviço por muito tempo seguido. Os bichos, ao que vão criando tundá, garram a copiar moda, a inventar treta, criam cócegas no lombo, uns ficam mesquinhos das orethas, coiceiros, dadores de patadas, danam a negar estribo nos primeiros dias de repasso.

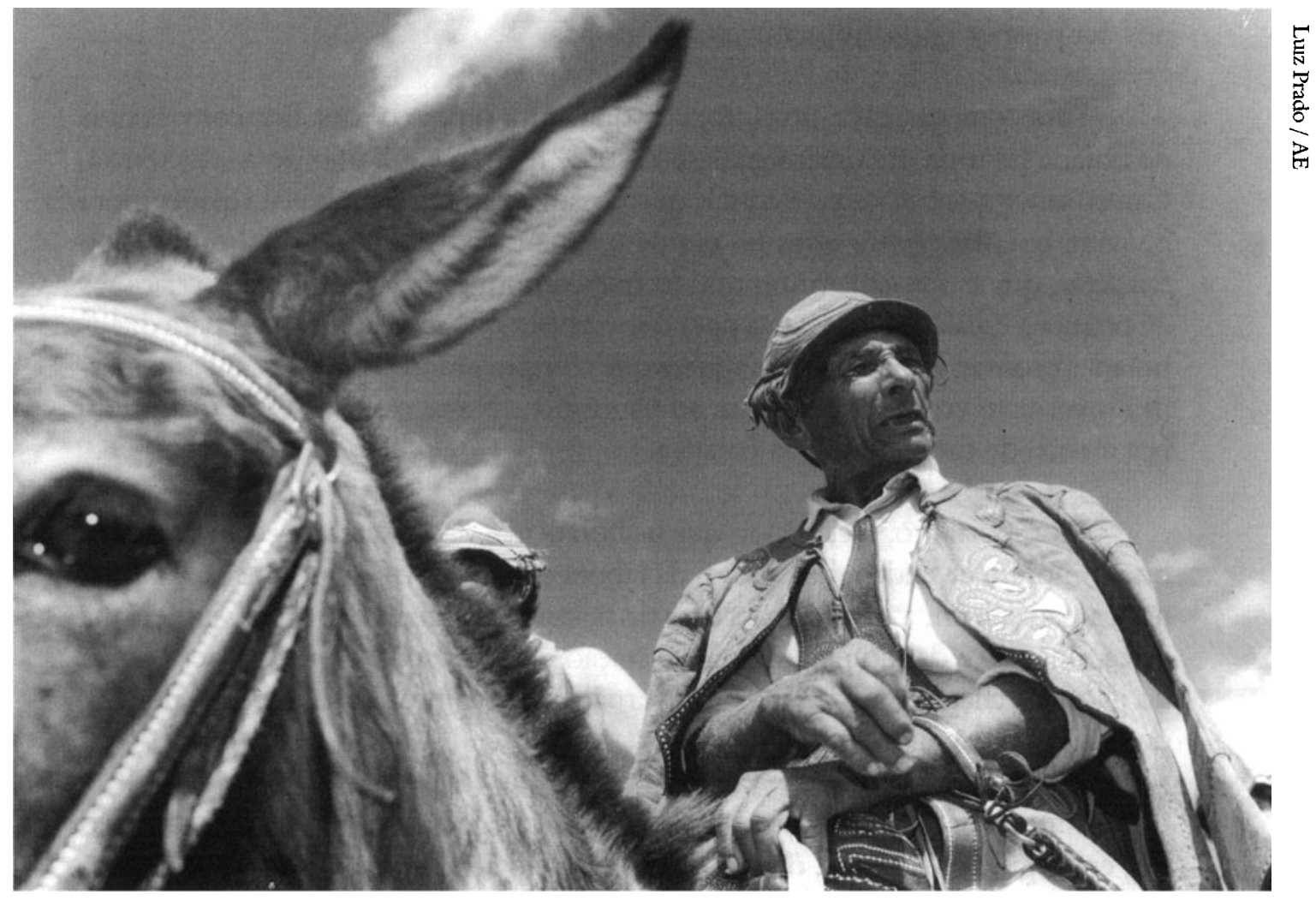

"Pode ser que no correr destes escritos venham a aparecer outras palavras e outros modos de dizer que caregam explicaçōes; $e$, nessas horas, iremos prestando os esclarecimentos que forem necessários, com calma $e$ paciência. A gente letrada que lê não tem culpa de ser ignorante das coisas e costumes do povo, de quem sempre andamos distantes".

Carece explicar o que certas palavras significam no linguajar dos peões. Espancar boi não quer dizer bater, não quer dizer judiar, torturar, conforme essa palavra é entendida no léxico da polícia. Na fala do peão, espancar boi é lidar com eles, tocar, pastorear, enfim, labutar com a boiada na estrada. Fazer a boiada é o ato de dois peóes se colocarem, um de um lado, outro de outro, na passagem de uma porteira ou em qualquer uma passagem estreita, com a finalidade de ir 
afunilando a ponta da boiada, contendo-a para que os bois não passem embolados e em atropelos, de forma a dar condiçóes ao contador, postado do outro lado, fazer a contagem direitinho, sem haver dúvida e sem erro. Esse, o serviço que se diz fazer a boiada.

- Negar estribo é o burro se arrancar danado, quando o peão pisa no estribo e joga o corpo para ganhar a sela. É um negócio perigoso demais. Se o peão não for dos bons, de corpo leve e esperto, pode escapolir dos arreios e ser arrastado com o pé enganchado no estribo e se desgraçar todo, se os companheiros não estiverem perto, que possam correr e acudir a tempo. Mesquinho é o burro que panha a manha de não deixar pegar-lhe nà orelha. Que dá patadas, refuga, distribui coices, para ser encabrestado; quando é assim, e não deixa socar-lhe o freio na boca, o peão tem que amarrar o beição dele com uma cordinha forte e macia, enfiar um cambito e torcer até danar, fazer o bicho rinchar num torniquete. $\mathrm{O}$ beiço torcido assim, dói por desgreta, o animal, por mais xucro que seja, se entrega e aceita ser encabrestado e mastiga o bridão sem bronca, manso e bonzinho. Niquento é o burro ou mula que tendo ficado muito tempo à-toa, sem ninguém montar, panha cócegas no lombo e não aceita jogar-lhe em cima nem os baixeiros. Nesse caso, a solução tem que ser também torcer-lhe o beiço, operaçáo que $o$ peão chama passar bico-doce.

Pode ser que no correr destes escritos venham a aparecer outras palavras e outros modos de dizer que careçam explicaçóes; e, nessas horas, iremos prestando os esclarecimentos que forem necessários, com calma e paciência. A gente letrada que lê não tem culpa de ser ignorante das coisas e costumes do povo, de quem sempre andamos distantes.

\section{Tirar uma boiada}

Não se tira uma boiada, a não ser umas poucas cabeças, sem dividi-la em talhões. $\mathrm{E}$ o comprimento de uma fileira aí de mil bois em marcha dá bem a extensão de mais de dois quilômetros. Não a dividisse, a peonada teria de trabalhar emparelhada de flanco, de um lado e outro, indo e vindo num vai-lá vem-cá adoidado, e aí não haveria corpo a resistir a canseira, num dia só afrouxaria a tropa toda.

O expediente é irfazendo a trenheira numa fileira estreita, de quando muito umas quatro reses de fundo. Numa média assim de uns 100 bois entra um peão, toma conta do seu lote, e os talhóes seguem separados a uma distanciazinha uns dos outros. Usam rebenque de argola grande e de tala comprida alceada na munheca, e tangem largando arrufos de peito e dando chibatadas nas botas, como se estivessem passando sustos e espantos. 
O comprimento dos talhôes tem de ser na medida em que o peão possa enxergar de fora a fora o que ele toca, pois há de ser vigiado com argúcia a fim de - ver quando um boi gongueiro inventa a sair da fileira para se encafuar numa moita e ficar de arribada.

Está aí o tal caso: aparecem aqui duas palavras que o neófito para entendêlas carece de explicação: gongueiro é a criação que sabe esconder-se, amoitar para lograr o peão; e encafuar vem de cafua, que tanto pode ser uma choupana, uma moita fechada, como um esconderijo qualquer em que dentro a criação se oculta para passar desapercebida.

No comando dos talhões vão os peões comuns, o peão de boiadeiro que não é treinado noutra especialidade na condução de uma boiada; uma espécie assim de trabalhador braçal de salário mínimo. Cada um toma conta de uma ponta de gado; o seu serviço não é só ir tocando. Além disso, de ir espancando e mandando, cercando e tangendo, tem que não descuidar de seguir espiando sempre por cima do lombo da bicharada, botando sentindo a ver se algum não cospe da manada, principalmente nas passagens por estirões aonde a estrada entra nos trechos fechados, de mato sujo, de capoeira e de carrascal.

O peão conhece demais aquele que vai mal intencionado, no aguardo de um descuido para cair fora e arribar. Os bois vão submissos, de cabeça baixa, obedientes ao comando e aos aboios, às vezes até demonstrando satisfação em viajar; brincam com os companheiros, vez em quando, quando há folga, simulam uma briga, aqui e ali pegam uma bocada de capim nas beiras de barranco, saem mascando. Com esses assim, tudo bem: o peão pode ficar descansado. Agora, quando dentre esses um vai andando de cabeça alta, babando e com o queixo em cima da anca do da frente, piscando miúdo e nos olhos velhacos delata rancor, malsatisfação e ódio - tome cuidado com ele que esse daí vai dar aborrecimento. O peão já sabe: não deixa ele sair do meão, porque é só facilitar e o danado espirra fora da manada e estoura no mundo, e aí só trazido ao redil pego no laço. É serviço do peão arribista. Há boi assim, de natureza rebelde que chega ao desplante de saltar n'água, dentro dos ribeiróes nas passagens de ponte, e até mesmo a se atirar nos abismos e quebrar o pescoço, para a alegria da peonada: vai haver carne fresca na comitiva.

Na ponta da boiada vai o ponteiro, homem treinado nessa posição. Quem ver assim julga que é simples o serviço desse peão, e é onde está o engano. $\mathrm{Na}$ verdade, é ele que vai dando encaminhamento à fileira, guiando-a para os itinerários certos da estrada, tomando as encruzilhadas que tem de tomar, dando de lado se a manada inventa de esfarelar, contendo-a a fim de regular a marcha viageira e não deixar disparar. Ele dá arrufos de peito, espanca a bota com a tala do rebenque, 
a todo momento vira-se para trás, regula o passo da boiada, faz com que a marcha não exceda uma fluência a mais do que estão desenvolvendo os últimos talhões de trás, que a boiada toda venha marchando sem maior esforço.

Vez por outra toca o berrante. Tira uma nota monocórdia bem longa, no fim dá uns floreios e uns repicados que estremecem os ermos, a boiada vem serenando atrás, apacentada. A melopéia de um berrante bole fundo no coraçáo da peonada, que está sempre muito arreitada. Os homens vêm há dias sem mexer com mulher, massageando o vão das pernas no retouvo da sela, aquilo está que pega fogo debaixo d'água.

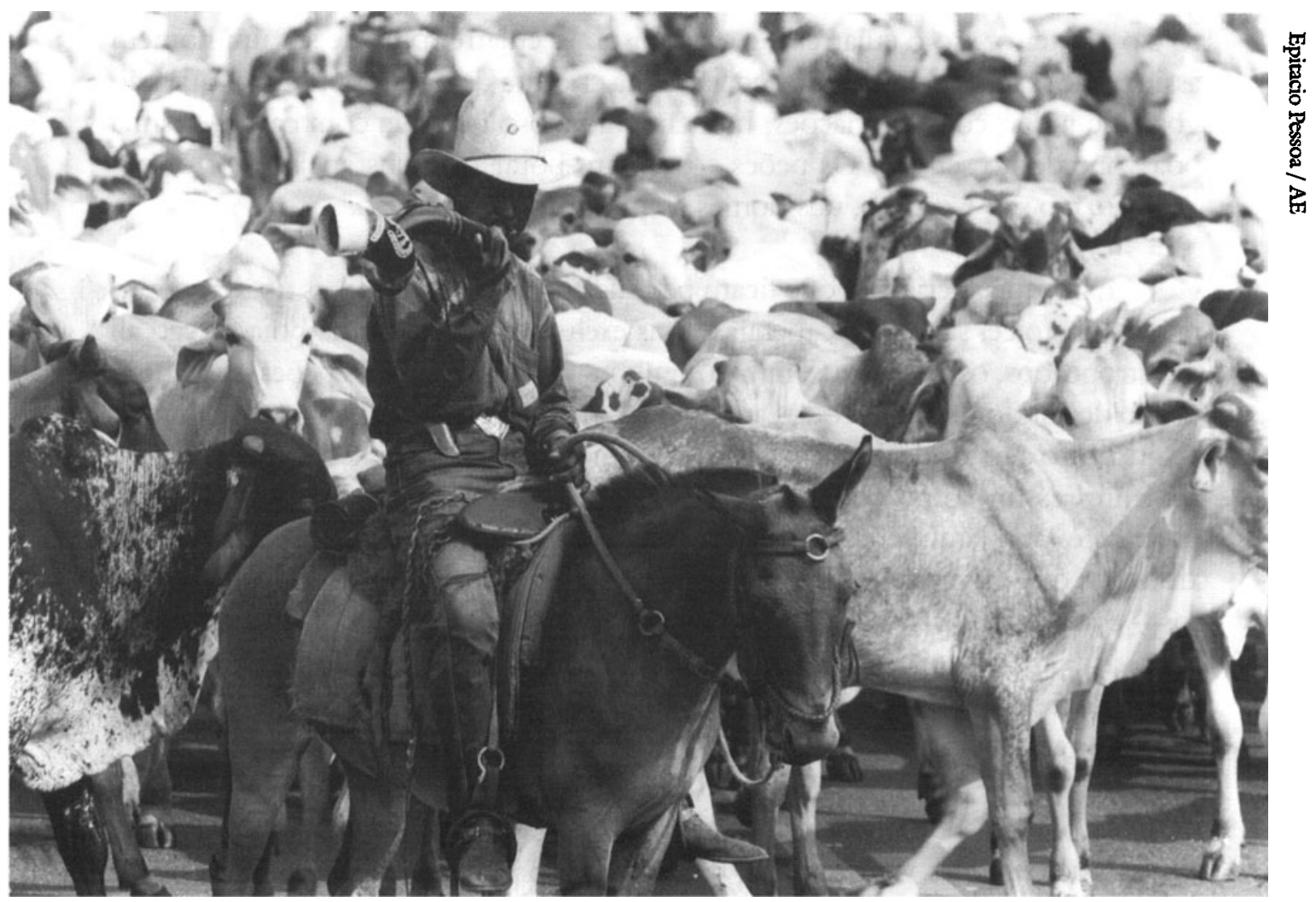

"Na ponta da boiada vai o ponteiro, bomem treinado nessa posiğ̄io; pez por outra toca o berrante".

Nos primeiros dias de marcha, a boiada está esperta. Há muitos bois pelo meio que se recusam à submissão, teimosos, não se entregam, é uma trabalheira lidar com eles. Depois, com o custeio e jornadas cansativas, os mais azougados vão sossegando. Vai indo quebram das carnes, chegam todos no que tem que ser. Nessas alturas, pegam a aparecer os xibungos (homossexual passivo). Parece que as fadigas da marcha, os esbrugos da viagem demorada - seja o contato de corpos se esfregando nos afogados das travessias, ou o quê, certo é que há um distúrbio 
a ressuscitar instintos mortos, que desencadeia desvios de comportamento e o boieco infeliz panha cheiro de fêmea, e os outros dão em cima dele, e é um deboche desgraçado. A todo momento lá vem o monjolo armado, um subindo no outro empurrando e dando peitadas, e é um trovejo danado. Vai indo o xibungo fica com os quartos esfolados, frouxo e capenga, é preciso ser tirado dos talhôes do meio e passado para a culatra, onde vêm os estropeados que não querem nada com nada.

\section{Uma boiada em marcha}

Outros que também têm que ser peões escolhidos, assim como o cozinheiro e o ponteiro, são o culatreiro e o arribista. $O$ culatreiro há de ser um homem assim, que seja pai e mãe da paciência. Uma criatura de natureza branda, que não goste de judiar com as criações, homem cuidadoso que lida com calma e tenha boa vontade no serviço. Os peões costumam botar nele uns apelidos: é o seoPacífico, é o seo-Cordato, uns nomes assim, ditos de adulação.

É porque as criações que ficam por sua conta, ele tocando-as no derradeiro talhão, no coice, são todas capengas, bois excluídos do grosso da boiada, vão ali os estropeados, os que afrouxaram nos talhóes da frente e que os peôes da dianteira vão deixando pra trás. Todos aqueles que fraquejaram, que racharam as unhas de encontro a tocos de paus e pedrais e vão mancando, os que se machucaram em acidentes assim como enfiar o pé em buraco e dar maljeito na junta, os que pisaram e afundaram em gretas de assoalho de pontes e saíram espaduados, os xibungos que restaram com os traseiros esfolados do trepa-trepa dos companheiros - esses assim, perrengues, de passo tardo, são os que restam no talhão que segue à reçaga da boiada, por conta do culatreiro. Então, ele há de ser uma pessoa assim, de natural bondoso, que vai devagar, peregrinando atrás, sem pressa, com sua farragem de criações claudicantes.

Já o arribista é o oposto. É um peão rasgador, bom no laço, destemido, desses que com eles vai ou racha, e no rastro do boi de arribada até farejar ele fareja. Seu serviço é o seguinte:

O boi arisco e o gongueiro logram o peão e tresmalham, e só se vai dar falta dele muito depois, na primeira contagem na frente. Sabe-se que a boiada tem de ser contada, se possível, todo dia, ou mais do que isso, conforme: se passou por trechos sujos da estrada, se o gado esfarelou no cerrado e deu trabalho para ajuntar e tornar a enlotar, e se no pouso o encosto não foi bem apropriado para conter a manada reunida. Aí tem que arrumar um jeito de fazer a boiada e contar.

O contador contou, deu falta, o arribista volta na arribada e vai campear, 
trazer o boi no menor prazo possível. Se demorar mais de um dia, a boiada retarda a marcha e espera. O ponto de honra do peão é não voltar sem, a escoteiro. Tem de trazer, ainda que seja o pedaço do couro tirado contendo a marca. É assim como o jagunço matador de gente, de profissão: traz a orelha do suplicante assassinado. Se o boi morreu, o arribista encontra a carniça e faz assim: traz a marca como prova de que não brinca em serviço. Ele é um que conhece todas as manhas do boi velhaco. Sabe em que bibocas é suscetível deles se esconderem para lograr o campeiro; está acostumado com as manhas desses tucuras treteiros, e separa sem erro os rastros do boi fugido da boiada dos das outras criaçóes empastadas, que não andaram tocadas. Nestes os cascos têm paredes que cortam o chão, e nos outros o rastro é espalmado de unhas gastas. Muitas outras regras e tudo quanto é segredo o peão arribista conhece; tem sabedorias que lhe vêm do instinto, estão na massa do sangue, coisa assim que ele mesmo não sabe explicar o por quê.

O laço ele traz na chincha, já uma vez. É amarrado abraçando pelo meio o burro mestre nesse serviço de trazer boi chinchado. É passado duas voltas no retouvo da sela, por cima da barrigueira e por baixo dos forros. Encontrado o boi - que ele acha mesmo, não tem dois tempos - corre nele o imbé. Imbé é uma espécie de cipó e é $o$ apelido que eles póem no laço. Aí apeia, o burro fica segurando, sempre com a frente virada para a direção que está o boi, e com outra corda derruba e peia o bicho. Ali fura-lhe a venta, passa uma alça com uma correia forte levada de propósito, e ali prende a ponta do laço, e pronto: está segúro e entregue; não debate, não esbirra, não forceja, nem nada. $O$ bicho sabe que se fizer ação dói a venta, e dessa forma, dominado, e domado à força, segue acompanhando o burro na frente puxando, manso e obediente feito um cachorro.

Quando é mais de um boi que ficaram na arribada, o peão pega-os um por um recolhendo-os numa fazenda. Quando não, vai amarrando-os nos paus do cerrado. Depois trela uns com os outros e toca, alcança a boiada. Se amarrar o boi no pau, de forma que ele não possa deitar (boi se passar muitas horas deitado empazina e não levanta mais), se ficar todo o tempo em pé, nesse caso com a testa unida no tronco da árvore, uma criação fica até três dias sem se abater demais. Sai meio trôpego, mas com pouco prazo desasna e anda, bom só.

O serviço de pegar boi brabo no campo é assim: vai pegando e amarrandoos no pau. Depois vem ajuntando, trelando-os no pescoço de bois mansos, os sineiros. $O$ arribista costuma também, para não ser preciso furar a venta, botar tapa na cara do boi, com uma garra de couro cru. O bicho, na condição de cabracega, sai dando topadas nos paus, e logo quebranta, ganha a estrada, vai-se embora direitinho, sem dar nenhum trabalho. 


\section{A tropa em marcha}

Um lote de burros - os oito cargueiros e o adestro - era o quanto cabia a um camarada tocar. Se acontecia de um ir com menos do que isso, era porque havia na tropa um lote desinteressado, assim como se tocasse a um coronel comandar um caco de batalhão, com efetivo de menos de 300 homens.

Pensando bem, é acertada essa palavra tocar tropa, pelo seguinte: o camarada fazia era seguir acompanhando o seu lote, dando encaminhamento à marcha, vigiando para não deixar haver avaria na carga, dando chilapadas no ar à-toa, rosnando arrufos. Nem que o camarada quisesse andar mais depressa, inventasse de estugar os burros com maior afinco, não iria adiantar nada. Os cargueiros tinham uma toada certa de viagem, pisavam num compasso picadinho de marcha que sacudia a carga no ritmo de um floco de espuma n'água rodando por sobre ondas de marolas miudinhas, com as arreatas e o correame chiando, e não saiam disso.

O cavalo de sela marchador às vezes chega a ter até três compassos de marcha, não contando o passo descuidado nem o galope de corrida. De um passo largo - topoc-topoc - o animal bom de sela, se estugado, passa para uma marchapicado de tirar légua e meia por hora, e se mais apertado pega um esquipadão que antigamente era o luxo da rapaziada. Nos seus machos esquipadores, os moços da casta dos gaúchos faziam proezas de cavalgadas tampando de poeira as ruas dos comercinhos. Volta e meia passavam por cima de pessoas, assim como a moçada de hoje dá cavalo-de-pau, e corre em duas rodas nos automóveis dos pais, e brinca com suas motocicletas, fazendo os cabelos das franguinhas na garupa esfarelarem ao açoite da ventania.

Já, com os burros ninguém tinha gosto de fazer isso. Marcha de burro é uma só; ele não sai daquela. Se lhe esporeia, ele só faz dar um pulo pra diante e imediatamente retorna ao picado da mesma marcha em que vinha. $\mathrm{Na}$ estrada $\mathrm{O}$ burro tem um natural de marcha, seja na sela ou na carga, não vai a mais nem a menos, e não pode ser contrariado. Nesse caso, o camarada que mandava um lote numa viagem só fazia mesmo tomar conta dele, mesmo porque, na sua ausência, os burros, sentindo que não tinha ninguém vigiando, acompanhando, paravam e deitavam com as cargas.

Uma adição que havia era que a burrada de uma tropa trazia decoradas todas as passagens da estrada por onde tinha costume de viajar. Conhecia os pontos dos descansos do meio-dia e dos pousos, e sabia tomar as medidas direitinho dos estirões de jornadas. A burra enfeitada de prataria e metais cintilantes e guizos tilintando na frente, puxando a marcha, ao que chegava nos pontos consignados de parada, atoava ali e pronto: na frente nem um passo, nem a pau. 
Demorassem os lotes atrasados a chegar, e sua carga não fosse logo derrubada, com pouco ela escolhia um arregoado no terreno por ali, que muitas vezes ela já conhecia de outras passagens por aquele lugar, deitava debruço dentro, de modo a aliviar o peso da carga, e lá ficava a espera de assistência. Era ela, na tropa, a que marcava os pontos de paradas na volta do dia e sabia a hora do pouso.

Quem ver contar essas coisas há de achar que derrubar as cargas de uma tropa e desarrear, seria serviço simples, que podia ser feito de qualquer jeito, sem nenhuma observância. A gente que escreve cá dos gabinetes não sabe que tudo tinha regra, obedecia a rituais. Ser camarada de tropa era um ofício que requeria iniciação. Os burros eram ensinados a tomar posiçôes certas para serem arreados e desarreados. Cada lote em sua formatura, na qual eles tinham que estar, em obediência a gritos e estalos de chicote, comandados pelos camaradas.

Os fardos dos costais eram derrubados de dois em dois ao mesmo tempo. Um camarada a pegar de um lado outro de outro, e iam sendo empilhados sobre estivas de madeira roliça, que sempre preexistiam nas estradas salineiras.

Por causa disso, para que se formassem as duplas certas de camaradas para trabalhar em conjugação de dois a dois no suspender e derrubar os fardos dos costais, é que úma tropa completa deveria ser em números pares de lotes. Cada dois camaradas tinham a seu cargo, nos descansos e nos pousos, labutar com dois lotes. Uma tropa de tamanho bom, era de seis lotes: $\mathbf{4 8}$ burros de carga e seus adestros, afora a burra da guia, os animais da comitiva, a madrinha, e mais dois particulares, um pertencente ao cozinheiro e outro ao arreeiro. Os camaradas viajavam de apé, com um embornal com suas coisas a tiracolo, calçados de precata de couro cru, chilep, chilep, o dia todo.

Nada era permitido ficar esparramado no chão, desorganizado. Cada burro, como é natural, tinha a sua conformaçáo de corpo; uns mais roliços, outros mais esguios, corpulentos uns, outros nem tanto. Por isso, a cada um se destinavam a cangalha, as arreatas e os dois costais que pegou no início da viagem e tinha que levar até o fim. Os camaradas tinham por força de trazer tudo arrumado, certinho nos devidos lugares, para que nada fosse trocado nem mesmo o cabresto, que também era um consignado para cada burro, sendo que cada animal apresentava um tamanho e uma conformação de cabeça. $\mathrm{E} o$ arreeiro estaria aí presente, botando sentido, fiscalizando tudo, determinando. Se na afobação de arrear a tropa, um burro recebesse, por um descuido, uma cangalha que não era a sua ele dava sinal na hora: sapateava, murchava as orelhas contrariado, e os camaradas notavam logo que estava errado, tinham de voltar atrás e reparar o engano.

Mas isso era muito raro suceder. 


\section{De como se arreava uma tropa}

As arreatas da tropa eram todas feitas em couro e sola crua; só não as armaçóes das cangalhas, sendo estas de montagem dos fardos e conforme fosse a mercadoria a transportar, tinha também por força de entrar o couro. Em assunto de tropa o couro era que falava a verdade.

No que ia de exportação do sertão pra fora preponderavam o toucinho salgado e acondicionado em rolos empalhados; o açúcar de engenho embalado em bruacas de couro, no que ia também a rapadura empalhada, couro de bicho e sola crua. E de fora vinham o sal principalmente, e toda mercadoria de loja. A embalagem disso tudo era feita em condiçóes de ser transportada em cargas de burro, e a mercadoria acondicionada a propósito para isso e de modo a não avariar com os boléus levados no correr da viagem. Os tecidos vinham enfardados, capeados com um papeláo grosso e arrochados com fitas de arco-de-barril; e a miudeza arrumada numas canastras de tamanho calculado para dar a medida de um costal na carga, e aferidas na balança de modo a não passar de três arrobas e meia cada uma, a metade do tanto de peso que um burro de tropa pegava para sacudir bem numa viagem de muitos dias.

Essas canastras, feitas de carregação (em série) tinham a forma de baú, umas caixas de fundo chato e tampa abaulada, eram armadas com tabuinhas, enfrascadas em papelão colado e guarnecidas com cantoneiras e tiras de folha-deflandres fininhas e rebrilhantes. Cá elas eram vendidas à freguesia nas lojas, vez que constavam nas faturas como mercadorias com seu preço estipulado. De pouca durabilidade por causa de serem feitas com muito papelão e madeirinha franzina, a fim de ficarem bem leves; mesmo assim, baratas, tinham boa saída e serviam bem para as noivas guardarem os seus enxovais de casamento.

Essas malas tinham que ser acondicionadas com alças para fazer delas costais. As cordas usadas nisso, quando não eram tiras de couro de anta ou correias torcidas como tamoeiros, restavam serem de seda de buriti, essas mesmas que ainda hoje índios aparecem vendendo por aí, nas feiras livres. Só que essas dos índios são cordinhas fininhas, e aquelas tinham de ser mais encorpadas, assim da grossura de um dedo.

Caixas e fardos tinham todos que serem guarnecidos com cintas largas de couro, e por cima delas passados os arrouchos das cordas feitas alças, a evitar que no atrito, as embalagens estragassem e afetassem a mercadoria lá dentro; $\mathrm{e}$, mesmo as cordas roçando de encontro às quinas das caixas iam desfiando e restavam toradas. 
De regra, todos os fardos tinham que ser encabeçados, tanto na frente como atrás, com dois cofos de couro cru, ligados de uma para outro com cordinhas. Nos fardos e nas canastras, essas guarniçóes de couro nos topos serviam para aparar encontroadas da carga nos paus e no sovar no mato crescido na beira dos caminhos. E nos outros, nos fardos de toucinho e nos de sal prinicipalmente, esses encabeçamentos, além de valerem como reforço, tinham uma serventia maior. Sem eles o burro de trás mordia e furava a carga do da frente, na tinhanha de se salitrar, e ele mesmo aprendia a volver o pescoço e morder nos topos da sua própria carga.

Dito que já foi e aqui vai repetido, em tudo numa tropa entrava o couro de boi como principal cabedal. A armação das cangalhas, essas eram duas forquilhas de pau, escolhidas no mato à feição de se ajustarem na conformação do lombo do animal, depois delas trabalhadas. De preferência o cangalheiro escolhia o piquizeiro e a sicupira, espécies bem resistentes e que nos galhos apresentam muitos cortes a escolher, e são de fibras revessas em competência para agüentarem o rojão. Os suadores, ao modo de travesseiros, eram de couro do lado que tocavam na madeira das armações, e de um pano de seriguilha grossa nas almofadas que assentavam diretamente no lombo do animal; o enchimento, o mais comum, era de folhinhas secas de um pau do cerrado chamado fava-de-arara. Tem também um capim de touceira, da folha chata feito fita, bem macio, por nome capim-mumbeca, mas esses tinham mais aplicaçáo no enchimento dos suadores das selas de montaria e nos colchões de dormida.

Dividindo em partes uma cangalha, cada uma tem seu nome: as duas pontas das armações de madeira, em que os costais eram alceados são os alções; vêm os suadores, vem um couro embainhado na borda da frente e na de trás, debruandose sobre uma guarnição na taquera esmagada, que é a capa da cangalha. Depois os arreamentos: o peitoral, a barrigueira, a sobrechincha, a aranha da retranca e o couro do ligal. Este consta de um couro de boi inteiro dobrado ao meio que trabalhava jogado por cima da carga; debaixo, entre um alção e outro, iam os dobros; e era a carga assim armada arrouchada com a sobrechincha num torniquete passado por um cambito. E segurando a sobrechincha de modo a ela não sair da posiçáo do meio da carga, corria uma correinha fina da frente da cangalha pra trás, travando por cima. Aí, das partes de uma carga, falta só citar o cabresto, que era simples, de cabo chato e curto.

Era de se notar que todas as peças que trabalhavam em contato com o corpo do animal - assim o peitoral, a barrigueira e a retranca - tinham por força de serem de sola crua. O couro cru, encharcado de suor o dia todo, esmolecia, virava uma geléia, e depois de enxuto ressecava e aí era vidro, quebradiço. 


\section{Os nomes dos burros}

É de se saber que os burros de uma tropa tudo tinham nomes; e o mais importante é que eles atendiam e obedeciam, se chamados, se ordenados. $\mathrm{E}$ os nomes de burro - é de se saber também - lhes eram peculiares: estavam fora do repertório com que nomeavam outras criaçóes: bois, vacas, cachorros.

Dos camaradas no remanejo da tropa, fosse em marcha, fosse comandando a ordem unida para cada um receber seu embornal de milho, ouvia-se aos gritos e aos arrufos, a nomeaçáo da burrada toda. Chibante, Completo, Tenente, Sodoso, Cabano, Trovão, Parceiro, Dourado; e aí ficava completo o efetivo do lote com o adestro extranumerário, que poderia atender pelo apelo de Soberbo.

As mulas também tinham a sua nomeação exclusiva, confusão nenhuma com os nomes dos burros: Mulata, Boneca, Baronesa, Pratinha, Revista, Ganjenta, Crioula, Sereia e Prendada, se fosse formado um lote completo só delas.

No comum, o burro de carga era só de carga, nenhum servia pra montar. Nem em pelo. Pior em pelo. Pusesse a sela no lombo de qualquer um deles, já no arrouchar o bicho estranhava. Na carga nunca eram arrouchados do tanto que era preciso o animal ser arreado com sela de montaria; havia até certos arreeiros que adotavam o uso da cangalha sem barrigueira, a carga firmada apenas com a sobrechincha, o equilíbrio feito no ouro-a-fio dos costais. Quando esses burros se viam torados pelo meio, com o látego trazendo a argola da barrigueira até topar na do travessão da sela, em cima, a estrangular-se a pança cosquenta, aí eles viravam um azougue. Não aceitavam aquilo de jeito nenhum. E aquele que acaso se resignasse à tortura do arroucho opressivo, montado não andava; se andasse não saía da sua toadinha de passo curto, do natural de sacudir a carga. Lerdo, queixudo, porque burro de carga nunca levava freio, nenhum dera acertado de rédea; montar um animal daqueles era o mesmo que montar numa tora de pau; uma tragédia.

Requisitava-se nos pousos umas poucas condiçóes: boa aguada, pasto bom nos encostos, e outras que os camaradas poderiam arrumar se as não houvessem adredes; que seriam jirau ou estiva onde botarem os fardos no resguardo da umidade $\mathrm{e}$ fora do alcance dos cupins, seriam as varas enfincadas de passar as cordas em que os burros tinham que encostar os traseiros, em forma, cada um no seu lugar estipulado, para receberem o embornal de milho da ração, à tarde.

Bonita, como uma festa, era a labuta de derrubar as cargas de uma tropa e desarrear. Os fardos iam sendo empilhados de par em par, as cangalhas alinhadas, 
embricadas uma dentro da outra, em seção de oito em oitó superposta, formando uma muralha; e tudo coberto com os coutos dos ligais, bem tapado contra sereno e chuva.

Desarreado, livre e desimpedido, todo burro deitava e rolava, esfregava o lombo no chão o quanto podia. Nenhum se retirava; ficavam todos por ali na expectativa, e aí começava a labuta de colocá-los na formatura requerida pelo ritual de receber o embornal do milho. Os camaradas, a poder de estralos do chicote, convocavam pelo nome os do seu lote. Iam chegando, e cada um virava o traseiro e iam entrando em forma, andando de fasto, até topar a bunda no fio de corda esticada de uma vara pra outra.

Ai daquele que se achegasse fora do seu lugar na formatura: Os parceiros dos lados murchavam as orelhas, ameaçavam a morder, dar patada, escoicear, $\mathrm{e}$ aquele intruso tinha que, mais que depressa, procurar sua posição, vamos dizer que fosse entre o Chibante e o Completo. O camarada apelava, brandia o chicote, puxava com os beiços uma sonorização mamada, e o Sodoso ia para o seu lugar, entrava de ré, enfiando cunha entre seus parceiros do trivial. Todos em linha, ensaiando orneios na ânsia do apetite, a cabeça avançada para o camarada enfiarlhes a capanga com litro e meio de milho dentro.

Capanga, embornal de couro, com a alça pregada nas bordas opostas às da costura, era colocado na cabeça do animal como se fosse um cabresto. Ali, para quem aprecia e sente o convívio com os animais, o prazer em ouvir o currucocurruco surdo da mastigação é algo indefinível. Os que iam terminando a sua suculenta porção davam um passo à frente, faziam menção de entregar o seu embornal vazio, e o camarada assentava-lhes o pelo encascorado de suor seco com passadas enérgicas da raspadeira; $\mathrm{e}$ ia liberando um por um para serem levados ao encosto, enlotados todos com a egüinha, madrinha da tropa.

Nessas alturas, o cozinheiro já havia chegado, já ia fritando a carne seca cheirosa, e daqui a pouco os camaradas se regalavam com o feijão tropeiro bemmexido com farinha de mandioca e o arroz maria-isabel, em que era preciso garimpar duro para encontrar um pedacinho de carne minúsculo. Se o tropeiro ia com a tropa, o dele era feito separado, em panelinhas menores, servido por derradeiro, com a toalha alva sobre suas malas tauxiadas servindo de mesa.

No cair da noite, sempre havia um camarada pândego que tocava machete, ou um que batia a corda de um berimbau improvisado, feito do cabo da palma dum coqueiro: acuri ou babaçu ou indaiá. $O$ patrão sempre liberal determinava 
ao arreeiro que corresse uma dosezinha de pinga na negrada, que eles ficassem meio requentados e melhor descantassem suas toadas lânguidas, os ponteados das cordas sempre no compasso da marcha da tropa.

Carmo Bernardes (mineiro radicado em Goiás) é jornalista e escritor. Vem escrevendo, desde os anos 60 , contos, crônicas e romances regionalistas de alta qualidade literária, como: Vida Mundo (1966, esgotado); Rememórias, I e II (1969); Jurubatuba (1972); Regaça (1972); Areia Branca (1976); Idas e Vindas (1977); Memórias do Vento (1986); Jangala - Complexo Araguaia (ensaios, 1994). 